症例

高ガストリン血症，A型胃炎を伴った多発微小胃カルチノイドの 1 例

香川労災病院外科

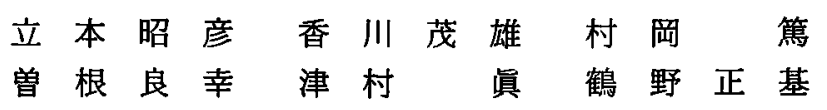

高ガストリン血症，A型胃炎を伴った多発微小胃カルチノイドの 1 例を経験した，症 例は68歳, 男性. 上部内視鏡検查で胃体部から穹薩部にかけ多数の微小ポリープを認め, 内視鏡生検により微小カルチノイド, endocrine cell micronest と診断された. 血清ガス トリンは $3,000 \mathrm{pg} / \mathrm{ml}$ と高值を示したが，セロトニンは正常值であった。胃全摘術を施行 し, 病理学検査にて, A 型胃炎を伴った多発胃カルチノイドが確認された。術後, 血性 ガストリンは正常化し, 術後経過良好である.

高ガストリン血症，A型胃炎を伴った多発性胃カルチノイドに対する治療としては， その発生母体となる胃底腺領域とガストリンを産生する G 細胞を完全に切除するため に, リンパ節郭清を伴う胃全摘術が基本的に必要であると考えられた。

索引用語：胃カルチノイド, 高ガストリン血症, $\mathrm{A}$ 型胃炎

はじめに

胃カルチノイド腫瘍は単発性のことが多く, 多発性 で高ガストリン血症を伴った胃カルチノイドは稀な疾 患である。

今回われわれは, 高ガストリン血症, A 型胃炎を伴 った多発微小胃カルチノイドの1例を経験したので若 干の文献的考察を加文報告する。

なお,リンパ節等の記載は, 胃癌取扱い規約（改言了 第12版）に準じた.

\section{症例}

症例：68歳, 男性.

主訴：心窩部不快感。

家族歴：特記すべきことなし.

既往歴：40歳, 狭心症.

現病歴：狭心症にて当院内科通院中, 平成 9 年 3 月 頃より心窩部不快感を訴え, 胃内視鏡検查を施行. 多 発ポリープを認め,生検にてカルチノイドと診断され, 手術目的にて外科紹介となった。

入院時現症: 貧血, 黄疸なく, 腹部は平坦軟で肝, 脾は触知せず。また，カルチノイド徵候も認めなかっ た。

入院時血液生化学検査成績: 一般血液検查, 生化学

1999 年 9 月 6 日受付 2000 年 4 月 28 日採用
検査に異常を認めなかった，内分泌学的検査では，血 清, 尿中 5 -HIAA および血清ガストリンが高值であ り,免疫学的検查では抗胃壁細胞抗体が陽性を示した。 なお, 腫場マーカーは正常範囲内であった（表 1 )。

上部消化管 X線造影所見：仰臥位二重造影像では, 胃体部後壁に散在した山田II型の小隆起多数認めた (図 1 ).

上部消化管内視鏡所見 : 胃体部を中心に, 直径 3 〜 $5 \mathrm{~mm}$ の山田 II 型の微小ポリープを多数認め(図 2 ), これらの生検にてカルチノイドと診断された.

腹部 CT 検查 : 肝転移や, 胃所属リンパ節の腫脹を 認めず，他臟器にも異常は認めなかった。

以上より，高ガストリン血症を伴う多発性胃カルチ ノイドと診断し, 平成 9 年 8 月 15 日胃全摘術および D $1+$ No. $(7 ， 9)$ を施行し, 二重空腸襄間置術にて再 建した.

切除標本肉眼および組織学的所見 : 胃体部から穹䈃 部にかけ胃底腺の萎縮が存在するA型胃炎を認めた.

胃を $7 \mathrm{~mm}$ 間隔で短冊状に全割し組織学的に検索し た. 直径 $0.1 \mathrm{~mm}$ 以上の微小カルチノイド腫場（図 3) を29個，また内分泌細胞の小さな胞巣 (endcrine cell micronest : ECM) を概算で約 6,000個確認し，その分 布を示したものが図 4 である.

フォンタナ・マッソン染色を施行すると, ECM や微 
表 1 入院時検查成績

\begin{tabular}{|c|c|c|c|c|c|}
\hline 末末梢血歈要 & & & BUN & 20 & $\mathrm{mg} / \mathrm{dl}$ \\
\hline RBC & 432 & $\times 10^{4} / \mathrm{mm}^{3}$ & $\mathrm{Cr}$ & 0.89 & $\mathrm{me} / \mathrm{de}$ \\
\hline WBC & 45 & $\times 10^{2} / \mathrm{mm}^{3}$ & $\mathrm{Na}$ & 140 & $\mathrm{mEq} / \mathrm{l}$ \\
\hline Hb & 13.7 & $g / d d$ & k & 4.2 & $\mathrm{mEq} / \mathrm{o}$ \\
\hline $\mathrm{Ht}$ & 40.0 & $\%$ & $\mathrm{Cl}$ & 106 & $\mathrm{mEq} / \mathrm{l}$ \\
\hline PIt & 19.8 & $\times 10^{4} / \mathrm{mm} 3$ & FBS & 85 & $\mathrm{mg} / \mathrm{ml}$ \\
\hline 生化平换查 & & & 内分泌業的樻查 & & \\
\hline TP & 6.8 & $g / d d$ & Gastrin & 3000 & $\mathrm{pg} / \mathrm{ml}$ \\
\hline ALB & 4.2 & $g / d l$ & Serotonin & 75 & $\mathrm{ng} / \mathrm{ml}$ \\
\hline T.Bil & 1.2 & $\mathrm{mg} / \mathrm{dl}$ & 血深5-HIAA & 38.1 & $\mathrm{ng} / \mathrm{ml}$ \\
\hline GOT & 19 & IU $/ 0$ & 尿中5-HIAA & 5.8 & $\mathrm{ng} / \mathrm{ml}$ \\
\hline GPT & 14 & IU/0 & 免疫学的槍查 & & \\
\hline LH & 132 & IU/e & \multicolumn{2}{|c|}{ 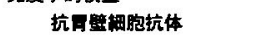 } & $(+)$ \\
\hline ALP & 241 & $\mathrm{IU} / 0$ & \multicolumn{2}{|c|}{ 抗ミトコンドリア抗体 } & $(-)$ \\
\hline $\mathrm{Ch}-\mathrm{E}$ & 405 & $10 / 0$ & \multicolumn{2}{|c|}{ 抗平湩的抗体 } & $(-)$ \\
\hline$r$-GTP & 13 & $\mathrm{U} / \mathrm{Q}$ & 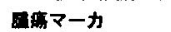 & & \\
\hline LAP & 28 & $10 / 0$ & CEA & 0.7 & $\mathrm{ng} / \mathrm{ml}$ \\
\hline S-Amylase & 128 & $\mathrm{IU} / \mathrm{mb}$ & CA $19-9$ & 10.0 & $\mathrm{U} / \mathrm{ml}$ \\
\hline
\end{tabular}

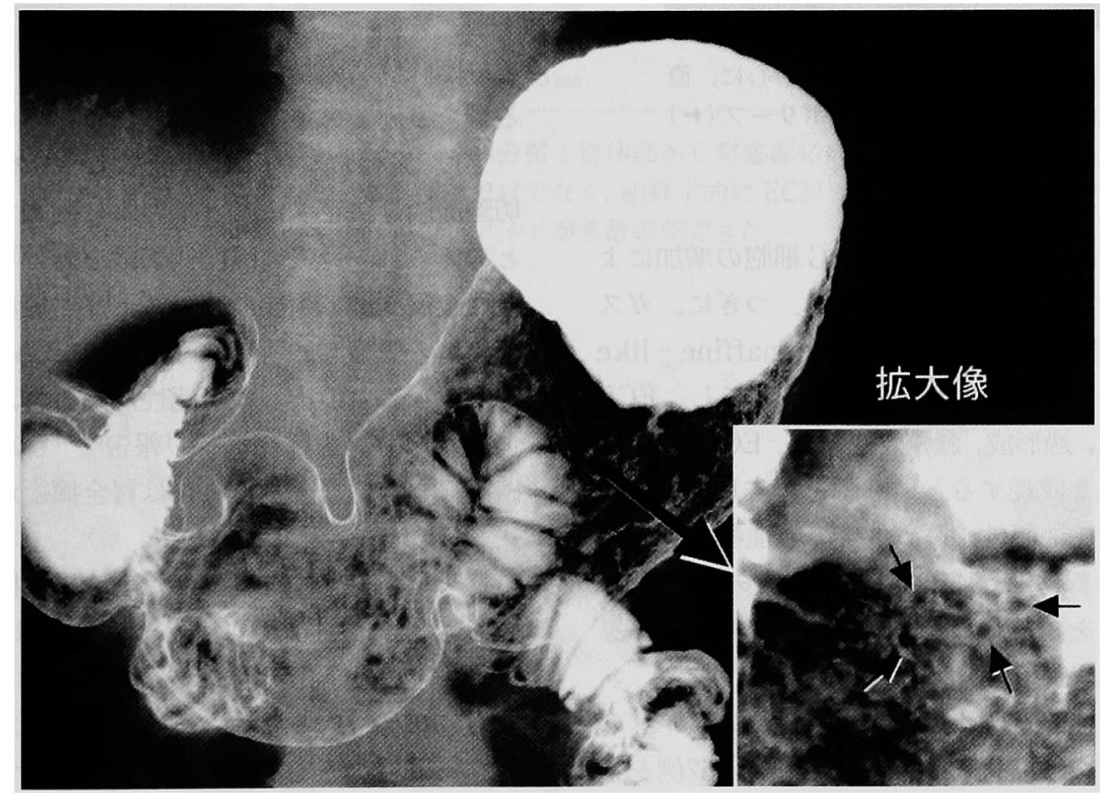

図 1 上部消化管X線造影：仰臥位二重造影像では, 胃体部後壁に散在した山田II 型の小 隆起（ト）を多数認めた。

小カルチノイドの細胞質に黒く染まる銀還元反応陽性 像（図 5 a ）を，グリメリウス染色では，好銀反応陽

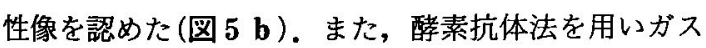
トリンを染色すると, 幽門腺領域に G cell の過形成を 認めた。

なお,カルチノイドの深達度には粘膜層までであり， リンパ節転移は認めなかった. 以上より，手術所見は， Stage I a $\left(\mathrm{T}_{1} \mathrm{~N}_{0} \mathrm{P}_{0} \mathrm{H}_{0} \mathrm{M}_{0}\right)$, Cur $\mathrm{A}$ であった.

術後経過は良好であり，血清ガストリン值は39pg/ $\mathrm{ml}$ と速やかに正常化し, 手術後 1 年 7 力月を経過した
が再発は認めていない.

\section{考察}

胃カルチノイドは比較的稀な疾患であり，本邦では 現在までに約400例が報告されている1)。しかし，その 多くは単発性であり, 多発性胃カルチノイドの症例は 少なく，全体の16.6\%と報告されている ${ }^{2)}$.

多発性胃カルチノイドの発生機序に関し，伊津野 ら ${ }^{3)}$ は，A型胃炎 ${ }^{4} に$ 伴う高ガストリン血症がその一因 と考えている。すなをち抗胃壁細胞抗体により胃底腺 領域に萎縮性変化を起こし, 無酸症を生じるため, neg- 


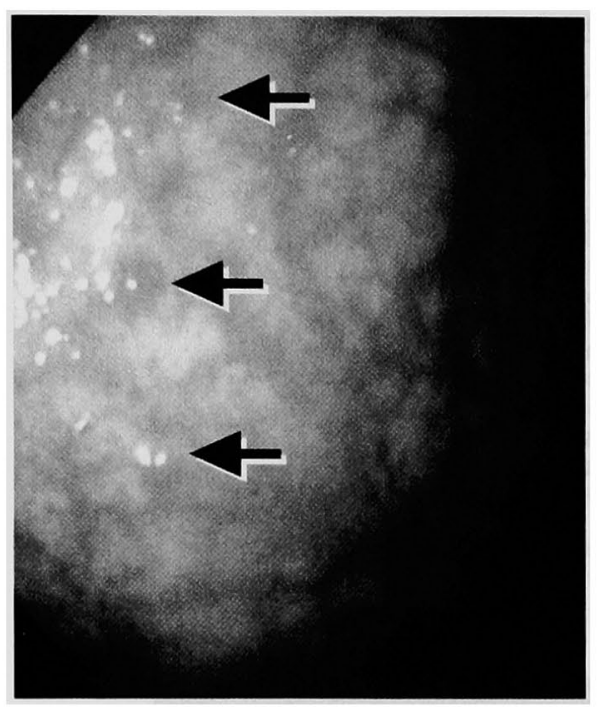

図 2 上部消化管内視鏡：胃体部を中心に，直 径 3〜 $5 \mathrm{~mm}$ の山田 II 型の微小ポリープ(ヶ) を多数認めた。

ative feedback により幽門腺領域の $\mathrm{G}$ 細胞の増加によ る高ガストリン血症が引き起こされる，つぎに，ガス トリンが胃底腺領域の enterochromaffine - like (ECL) 細胞に対して trophic action を起こし, ECL 細胞の増生促進, 過形成, 腫場化を経て, ECM および カルチノイドへと成長するという説を報告している. 自験例も抗胃壁抗体陽性, 高ガストリン血症を伴うA 型胃炎であり，胃体部から穹嶐部にかけ多数の ECM やカルチノイドを認めたことからも，この発生機序を 裹付けるものと思われた。

高ガストリン血症を伴った多発性胃カルチノイドの 本邦報告例に関しては，安田ら ${ }^{57} は ， 1997$ 年に52例を集 計し, 男性28例, 女性24例, 平均年齡50.6歳であり, 血清ガストリン值は平均 $1,829.2 \mathrm{pg} / \mathrm{ml}$ と高值を示 し, 全例 $\mathrm{A}$ 型胃炎を伴い, 発生部位は胃底腺領域であ った. また，樑達度はすべて粘膜固有層ないし粘膜下 層に限局したもので, 施行された術式は, 胃全摘29例, 噴門側胃切除 6 例, 胃覀全摘 4 例, 契状切除 1 例, 不 明12例であったと報告した。

本疾患の外科治療を考えるに，EMC および微小カ ルチノイドの完全切除とその発生を防止することが不 可欠である，そのため，胃切除の範囲を考慮した．次 の3 の術式が考えられる.1) ECM 発生母地となる胃 底腺領域を切除する噴門側胃切除術, 2 ) ECL 細胞を 腫瘍化するガストリンを分泌する $\mathrm{G}$ 細胞を切除するた

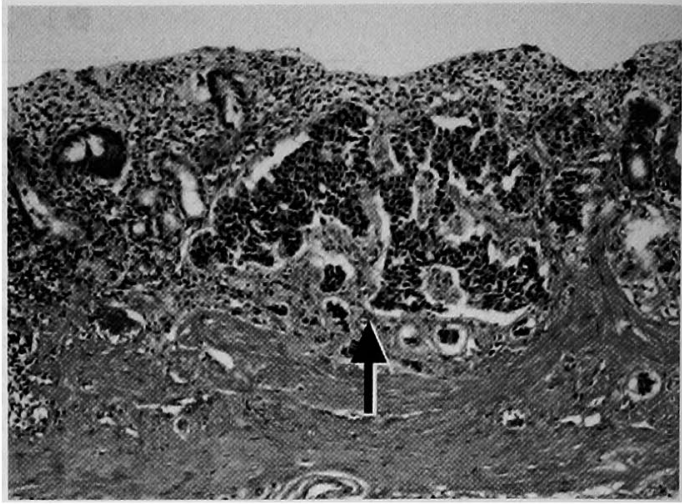

図 3 病理組織学的所見：粘膜内に索状構造を示すカル チノイド（ヶ）を認めた $(\times 50)$.

めの幽門側切除術.さらに，3) 両者を同時に切除す る胃全摘術である。

1)，2）は理論的には可能であっても，実際的には， 切除範囲を決定することは非常に困難で不確実な術式 と考えられ，過去に噴門㑡切除を施行した 2 例，およ び亜全摘 1 例に術後血清ガストリン值が正常化せず, 摘出胃の組織学的所見から残胃に ECM もしくは微小 カルチノイドの遺残の可能性が疑われ，やむなく残胃 全摘の再手術を行ったとの報告 ${ }^{6)-8) も あ る こ と か ら ， ~}$ 確実な根治性を得るためには胃全摘術が最も有効な術 式と考えられた。

しかし，一方，本疾患に対する胃全摘術は過大手術 であるとの批判もあり, 術後の機能障害やQOL を改 善するために，再建術式の工夫が必要と考えられた。 今回のわれわれの症例も再建法として二重空腸莘間置 術を採用し，術後良好な QOL が得られている。

次に,リンパ節郭清に関しては，多発性胃カルチ， イドの 2 例に第一群リンパ節転移を認め910)たとの報 告があり，低率とはいえリンパ節転移の可能性がある ため, 胃癌に準じた $\mathrm{D}_{2}$ 郭清が必要と考えられた。しか し，症例が少なく郭清度に関しては今後の課題と考兄 られた。

また遠隔転移に関しては, 肝転移 (H 1$)$ が 1 例 ${ }^{11}$ 報 告されており，術前に注意深い検索が必要と考えられ た.

以上から，高ガストリン血症，A型胃炎を伴った多 発性胃カルチノイドに対し，リンパ節郭清を伴う胃全 摘術が外科治療の基本術式と考えられた.

本邦ではA 型胃炎の発生頻度は少ないとされている 


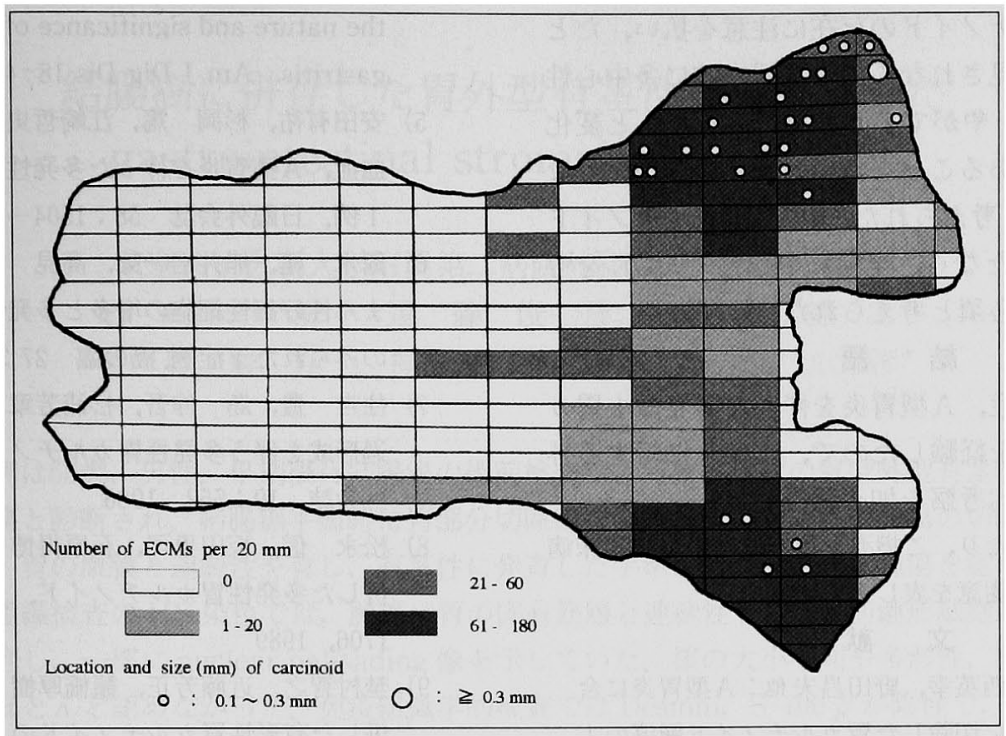

図 4 カルチノイドおよび ECM の分布：胃体部から穹䓝部に肉眼的隆起病巣と して存在するカルチノイド腫惕だけでなく, 組織学的に ECM や大型の ECM で リボン状構造を示す微小カルチノイドが多数確認できた。

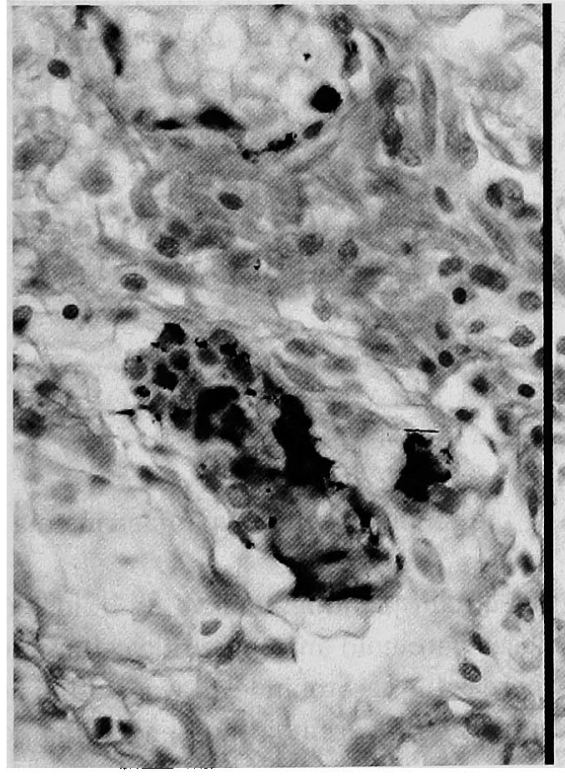

a

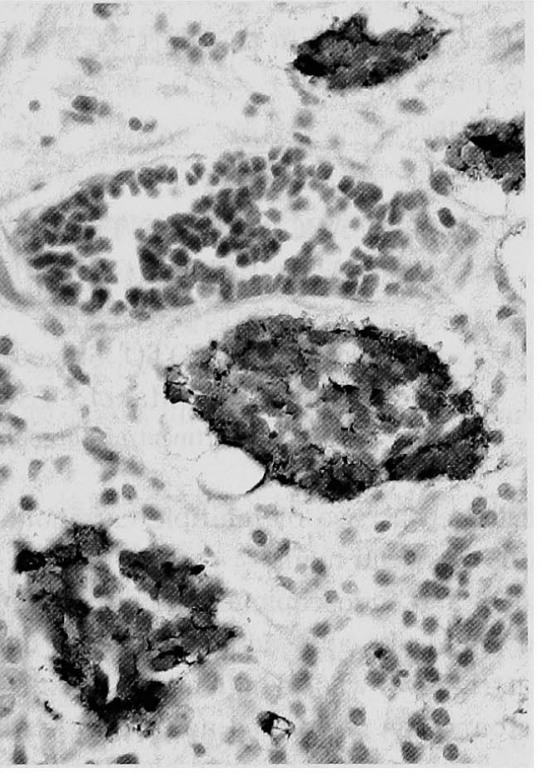

b

図 $5 \mathbf{a}$ フォンタナ・マッソン染色：ECM や微小カルチノイドの細胞質に黒く染まる銀 還元反応陽性像を認めた $(\times 150)$.

b グリメリウス染色：好銀反応陽性像を認めた $(\times 150)$. 
が，高ガストリン血症を伴ったA型胃炎に対しては， 胃底腺領域のカルチノイドの存在に注意を払い，たと え，その時点で発見されなくても，将来的に多中心性 に ECM が発生し，やがて多発カルチノイドへと変化 していく可能性があることを常に念頭に置き，充分な follow upが必要と考えられた。そして,カルチノイド の発生が確認されたなら，早期に根治性と QOL を考 慮した外科治療が必須と考えられた。

\section{結 語}

高ガストリン血症，A型胃炎を伴った多発微小胃力 ルチノイドの 1 例を経験したので，本疾患に対する外 科治療に関し文献的考察を加え報告した。

本稿を終えるにあたり，ご指導を頂きました当院臨床病 理, 溝㴊光一先生に謝意を表します。

$$
\text { 文献 }
$$

1）中島 誠, 小西英幸, 野田昌夫他：A型胃炎に合 併し内視鏡的に切除した胃カルチノイド腫晹の 1 例. Gastroenterol Endosc 36:2438-2443, 1994

2) 和田英利, 秋山俊夫, 井本一郎他：4 年間経過観 察し, 高ガストリン血症, 高ヒスタミン血症を呈 した胃カルチノイドと原発性胆汁性肝硬変合併の 1 例. Gastroenterol Endosc 24:930-935, 1982

3) 伊津野稔, 渡辺英伸, 岩淵三哉他: 萎縮性胃底腺 粘膜に見られた多発性カルチノイド．癌と臨 $29: 915-922,1983$
4) Strickland RG, Mackay IR : A reappraisal of the nature and significance of chronic atrophic gastritis. Am J Dig Dis 18:426-440, 1973

5）安田有祐, 杉岡 篤, 江崎哲史他：高ガストリン 血症，A型胃炎を伴った多発性胃カルチノイドの 1例。日臨外会誌 $58 ： 1504-1508 ， 1997$

6）露木 建, 熊井浩一郎, 高見 博他: 胃体部にび まん性好銀性細胞の增多と多発性胃カルチノイド のみられた 1 症例. 癌の臨 $27: 1298-1299,1981$

7）住吉 豊, 島 伸吾, 杉浦芳章他: 胃内分泌細胞 過形成を伴う多発性胃カルチノイドの 1 例. 日消 外会誌 $19: 552,1986$

8）松永 信, 坂田勇司, 石原得博他：悪性䆩血を合 併した多発性胃カルチノイド．日消外会誌 22 ： 1706, 1989

9）埜村智之，近藤芳正，籠橋厚樹他：A型胃炎に合 併した有形性胃カルチノイドの1 例一本邦報告例 の集計と考察一. Gastroenterol Endosc $32: 83$ $-92,1990$

10）三好信和, 中井隼雄, 中光䈆志他：胃多発性カル チノイドの 2 例。日消外会誌 $22: 1705,1989$

11）佐藤孝示, 加藤俊幸, 丹羽正之他：多発性隆起性 病変で発見された胃カルチノイドの 1 例. Gastroenterol Endosc 22:1264-1273, 1980

\title{
MULTIPLE CARCINOID OF THE STOMACH WITH HYPERGASTRINEMIA AND TYPE A GASTRITIS - A CASE REPORT-
}

\author{
Akihiko TATEMOTO, Shigeo KAGAWA, Atsushi MURAOKA, \\ Yoshiyuki SONE, Makoto TSUMURA and Masaki TSURUNO \\ Department of Surgery, Kagawa Rosai Hospital
}

We experienced a case of multiple carcinoid of the stomach with hypergastrinemia and type A gastritis in a 68-year-old man.

Radiological and endoscopic examinaitions revealed multiple minute elevated lesions ranging from the upper body to fornix, and endoscopic biopsy disclosed carcinoid and endocrine cell micronest (ECM). The serum gastrin level was as high as $3000 \mathrm{pg} / \mathrm{ml}$, whereas the serotonin level was within normal range. Total gastrectomy was performed and multiple minute gastric carcinoid and endocrine cell micronest with type A gastritis were confirmed histologically.

After operation, the serum gastrin level normalized and the patient has been doing well.

In the treatment of multiple gastric carcinoid with type A gastritis, total gastrectomy with lymph node dissection should be the standard operative procedure, in order to accomplish complete resection of the fundic gland area, which can be the origin of carcinoids and ECM. 